\title{
Planning private spaces for design students to support the optimization of online learning
}

\author{
A. Farida, W. Liritantri \& M.S. Hanafi \\ Telkom University, Bandung, Indonesia
}

\begin{abstract}
As an effort to prevent the spread of the COVID-19 outbreak, the government stipulated that all tertiary institutions eliminate lecture activities on campus and pivot to online lecturing. However, this change resulted in several problems for students, one of which regarding space in which to learn from home. Because of that, space design is needed to support students to perform online learning more sufficiently both in terms of space layout and adequate facilities. This design was made based on the results of a questionnaire from 100 varied design students majoring in interior design, architecture, products, visual communication, and craft. The design students as a subjects (as subjects) were chosen because the nature of their assignments were more dynamic so that their facilities needed to become more diverse. This design was carried out using qualitative methods, namely analyzing questionnaire data as well as quantitative data with descriptive analysis from literature studies. By designing this online learning space, it is hoped that students can optimize the online learning process.
\end{abstract}

Keywords: space, optimization, online learning, layout, facilities

\section{INTRODUCTION}

This article is in response to the West Java provincial government policy which stipulated that face-to-face teaching and learning activities were to be postponed until January 2021. In addition, the Minister of Education and Culture, Nadiem Makarim, revealed that distance learning can be applied permanently after the COVID-19 pandemic is over. Teaching and learning activities using technology will be fundamental. The use of technology provides an opportunity for schools to do various models of learning activities. Based on this decision, careful planning for adequate an online learning space to support online learning is necessary. For design students, online learning has higher challenges because of the more dynamic and diverse nature of lectures. Lectures are not restricted only to theory classes, but also have to be taken into consideration with regard to practice studies and variations of assignments make the online learning process of design students more complicated.

The main problem such as lack of concentration in learning can be overcome by arranging the layout of the space to be more private. A clear domain separation will ensure proper control of privacy in the private space. An operational definition of privacy, namely avoidance of unwanted interactions with others, involves information flowing from person to person. Unwanted interactions can be controlled by rules (attitude, avoidance, hierarchy, etc.), through the meaning of psychology (withdrawal, daydreaming, intoxication, lack of appetite, etc.), through behavioral cues, by structuring activities in time (being a particular individual or group certain not met), through spatial separation, and through physical equipment (walls, fields, doors, curtains, locks — architectural mechanisms that selectively control or filter information) (Rapoport 1977).

In addition to setting the space as a private domain, the study room also needed adequate facilities. Referring to the theoretical basis, online learning spaces can be categorized as independent learning spaces. The minimum area ratio for independent study is $4 \mathrm{~m}^{2} /$ student, and facilities in the room 
must include: furniture, information equipment, and storage furniture (Badan Standar Nasional Pendidikan 2011)

\section{METHODS}

The research method was conducted using qualitative methods in the form of analyzing questionnaire and quantitative data with descriptive analysis from literature studies. Questionnaire data was synchronized with literature studies obtained from books, research journals, and the internet. The data was then be processed (then processed) and analyzed. The conclusions obtained from these results were the basis for creating models of online learning spaces

The data collection includes primary and secondary data. The primary data collection was carried out through a questionnaire and interview with the research subjects. Subjects were design student that already have experience with online learning activities from the previous semester. The primary data was supplemented by secondary data from print and electronic media.

\section{ANALYSIS}

\subsection{Questionnaire data}

\begin{tabular}{ll}
\hline Design Major & Total \\
\hline Interior & 55 \\
Textile and Craft & 4 \\
Visual Communication & 13 \\
Architecture & 14 \\
Product & 14 \\
\hline Total & 100 \\
\hline
\end{tabular}

Figure 1. Respondent major.

\begin{tabular}{ll}
\hline Being in Semester & Total \\
\hline $1-2$ & 17 \\
$3-4$ & 22 \\
$5-6$ & 25 \\
$7-8$ & 36 \\
\hline Total & 100 \\
\hline
\end{tabular}

Figure 2. Questionnaire. Source: Personal Source

Details of the questionnaire's responses can be seen in Figure 1, with a total number of 100 respondents with different design majors, specifically: interior design, textile and craft, visual communication, architecture, and products. Design student respondents were currently in various semesters ranging from semesters 1-8 (Figure 2).

\subsection{Identification of problems}

The results of the questionnaire found that when students do online learning activities at home, the majority of them do so in their bedrooms (Figure 3). Therefore, the appropriate planning of student 


\begin{tabular}{ll}
\hline Online Learning Place at Home & Total \\
\hline Separate study room & 3 \\
Bedroom & 75 \\
Guest room & 1 \\
Living room & 19 \\
Terrace & 2 \\
\hline Total & 100 \\
\hline
\end{tabular}

Figure 3. Online learning place at home. Source: Personal Source

\begin{tabular}{ll}
\hline $\begin{array}{l}\text { The Biggest Obstacle When Doing } \\
\text { Online Learning }\end{array}$ & Total \\
\hline Lack of concentration & 48 \\
Unavailability of adequate facility & 21 \\
Lack of privacy & 15 \\
External interference & 6 \\
Communication limitation & 10 \\
\hline Total & 100 \\
\hline
\end{tabular}

Figure 4. Online earning constraints. Source: Personal Source

private rooms, specifically bedrooms, as a means of online learning spaces needs to be done to support the requirements for appropriate learning activities.

From the data obtained it can be concluded (Figure 4) that the biggest obstacles felt by students when learning online are: lack of concentration, lack of facilities, and lack of privacy when learning online.

\subsection{Determination of technical needs}

The student bedroom, originally a room for rest, has become an online study room as well. Therefore, we must calculate the dimensions and facilities that can fulfill both of these space functions properly and appropriately in one room.

Standard dimensions of the space occupied by one person as a bedroom are seen in Figure 5. Figure 6 shows the standard dimension of a space occupied by one person as a study room.

\begin{tabular}{lll}
\hline Minimal Dimension & Capacity & Furniture \\
\hline $3.15 \times 2.25=7.09 \mathrm{~m}^{2}$ & 1 person & $\begin{array}{l}\text { 1 set of study tables and chair, 1 single bed, and 1 } \\
\text { wardrobe }\end{array}$ \\
\hline
\end{tabular}

Figure 5. Bedroom imension tandar. Source: Ernst \& Peter Neufert 2000

\begin{tabular}{lll}
\hline Minimal Dimension & Capacity & Furniture \\
\hline $2.38 \times 1.52=3.61 \mathrm{~m}^{2}$ & 1 person & $\begin{array}{l}1 \text { set of study table+chair, 1 piece of storage } \\
\text { furniture }\end{array}$ \\
\hline
\end{tabular}

Figure 6. Study room imension tandar. Source: Julius Panero 2003

To get more detailed dimensions, Figure 7 calculates in more detail what facilities are needed based on space and activity. 


\begin{tabular}{|c|c|c|c|c|c|c|}
\hline No & Space & Activity & Facility & $\begin{array}{l}\text { Measurement } \\
(\mathrm{PxL}) \mathrm{cm}\end{array}$ & Circulation & Total $\mathrm{m}^{2}$ \\
\hline 1 & Bedroom & $\begin{array}{l}\text { Sleeping, } \\
\text { Resting, } \\
\text { Changing } \\
\text { clothes, } \\
\text { Getting ready }\end{array}$ & $\begin{array}{l}1 \text { Single bed, } \\
1 \text { Wardrobe, } \\
1 \text { Storage } \\
\text { furniture }\end{array}$ & $\begin{array}{l}100 \times 200 \\
100 \times 60 \\
60 \times 60\end{array}$ & $30 \%$ & 5.1 \\
\hline 2 & $\begin{array}{l}\text { Study } \\
\text { Room }\end{array}$ & $\begin{array}{l}\text { Online } \\
\text { learning, } \\
\text { Doing } \\
\text { assignment, } \\
\text { Reading } \\
\text { books }\end{array}$ & $\begin{array}{l}1 \text { Table for } \\
\text { computer/laptop, } \\
1 \text { Table for } \\
\text { assignments, } \\
1 \text { Chair, } \\
1 \text { Storage } \\
\text { furniture }\end{array}$ & $\begin{array}{l}110 \times 50 \\
120 \times 70 \\
50 \times 50 \\
120 \times 45\end{array}$ & $30 \%$ & 3.3 \\
\hline
\end{tabular}

Figure 7. Bedroom and study room imension. Source: Personal Source

Although the bedroom and study room have different needs for facilities and activities, with the right layout it all can be arranged in one room. Students prefer to do the online learning process in their bedrooms because the bedroom is the most private room in the residence so that being in there can reduce distractions from external factors. Thus, good acquiescence with the student's private bedroom is very important to support the two different room functions.

The minimum dimensions for a bedroom are $5.1 \mathrm{~m}^{2}$, while for a study room it is $3.3 \mathrm{~m}^{2}$. Therefore, from the table above (Figure 7) we can conclude that the ideal room for resting and online learning has a minimum area of $8.4 \mathrm{~m}^{2}$, with the main facilities needed being one single bed, one wardrobe, one desk for working on college assignments, one laptop table for online lectures, study chairs, and two pieces of furniture for storage.

The spaces must also arrange to meet the different activities that must be facilitated inside it. For the bedroom, the activities are sleep, rest, changing of clothes, and getting ready. As for the learning space, the activities therein are online learning, doing assignments, and reading books. For these activity (activities), human space must be available in the form of a comfortable circulation space, and then a circulation space of at least $30 \%$ of the estimated space is needed.

In addition, there are also other factors that are needed and desired by students to support online learning such as facilities and tools that can accommodate learning activities, e.g., laptops, lamps, stationery, and bookshelves. Placement of sockets and a stable internet network are also things to consider. The comfort factor in the study room must also be considered because students will conduct online learning on average 2-4 hours each day. From the Figure 9 diagram below, it can be concluded that the things that must be considered to construct student comfort when doing online learning are room acoustics, space atmosphere, stable network, lighting, and pleasant air circulation.

\subsection{Design concept}

To ensure the privacy of each space in the bedroom, a clear separation of sleep or rest zones and study zones must be carried out. It is also useful for increasing student concentration while studying. Furniture layout is arranged so that when conducting lectures online these zones will not intersect one another. Adjusting the visibility of the laptop camera with the surrounding room, as well as setting a domain or apparent room divider between the bedroom zone and the study room zone must also be applied to the design of the online study room.

Layout of the facility settings are adjusted to each domain so that the effectiveness of the activity flow in each space is created. The size of the furniture is also adjusted to the effectiveness and comfort for the capacity of one student. The window placement is beside the study room to maximize the light and natural air to create pleasant space for study. 


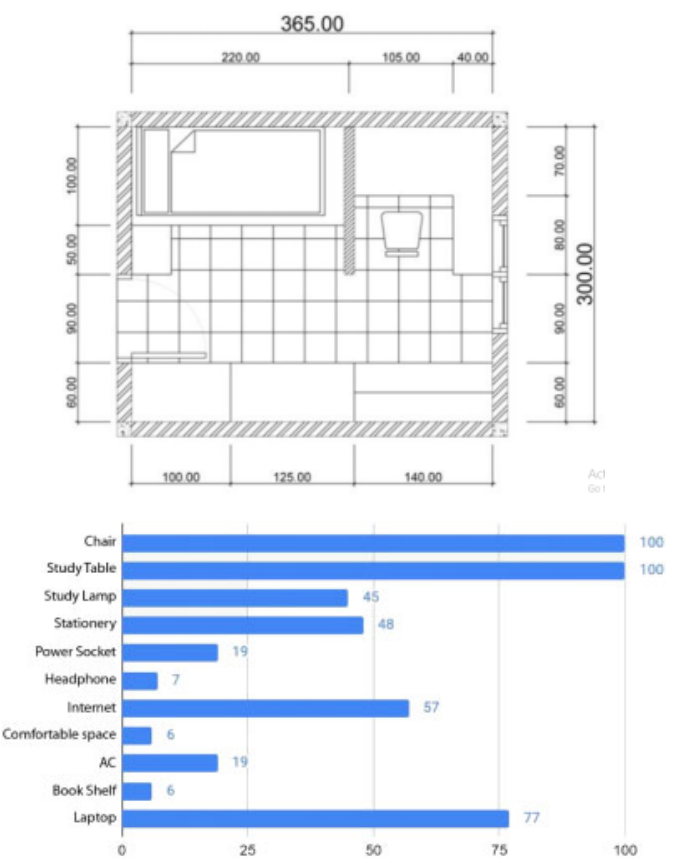

Figure 8. Other facilities. Source: Personal Source

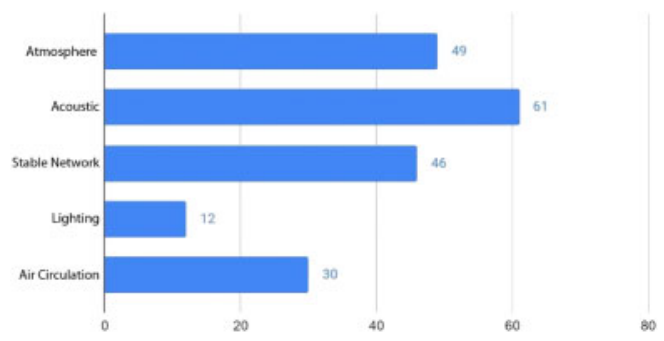

Figure 9. Comfort factor during online learning. Source: Personal Source

The colors used in the study room were bright colors that are soft. Bright colors are believed to increase concentration in the learning process such (as) egg yolk, sky blue, or salmon(,) (and) green (Trihanondo et al. 2017). In addition, bright colors can make the room feel more spacious. Bright colors can be combined with neutral colors so that the stimulus presented is not too excessive. However, for a study room that is located in the bedroom, students are advised to use bright colors that remain soft so that the main function as a resting room is not interrupted.

\section{CONCLUSIONS}

The shift from face-to-face lecture activities to online lecture activities resulted in several problems for students. The main problems arising from this shift are: lack of concentration, unavailability of adequate facilities, and lack of privacy in the online learning process. From research it is known that the place where the majority of students undertake online learning is in their private bedrooms. Therefore, planning a private bedroom as an adequate online learning space to support the learning process of students needs to be prepared. 


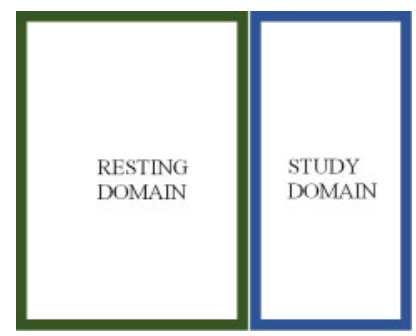

Figure 10. Bedroom layout. Source: Personal Source

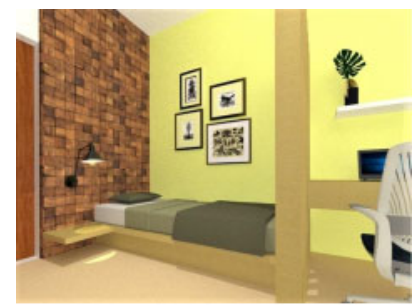

Figure 11. Perspective testing domain. Source: Personal Source

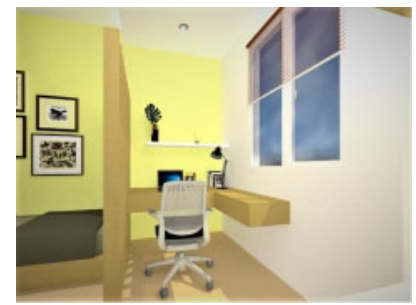

Figure 12. Perspective study domain. Source: Personal Source

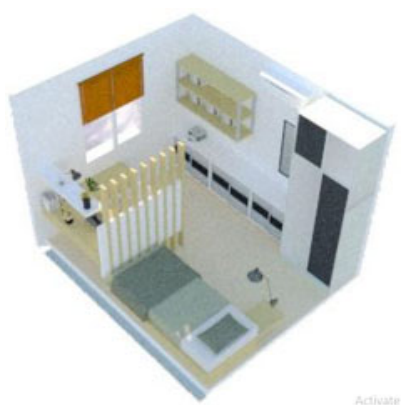

Figure 13. Perspective 1. Source: Personal Source

The minimum dimensions for a bedroom are $5.1 \mathrm{~m}^{2}$, while for a study room they are $3.3 \mathrm{~m}^{2}$. Then we can conclude that the ideal room for a place to rest and do online learning must be at least $8.4 \mathrm{~m}^{2}$ in size. The main facilities that must be included are: one single bed, one wardrobe, one desk for working on college assignments, one laptop table for online lectures, study chairs, and two pieces of furniture for storage. To ensure the privacy of each room, a clear separation of sleep or rest zones and study zones must be carried out. In addition, the atmosphere and comfort of online study rooms also needs to be considered because students will conduct online learning 


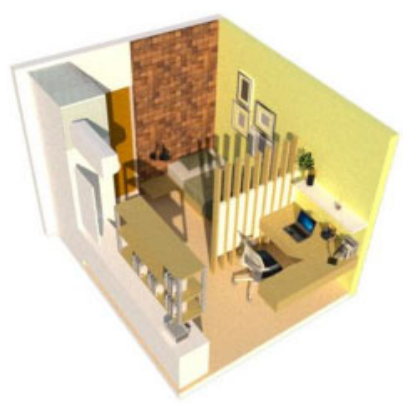

Figure 14. Perspective 2. Source: Personal Source

\begin{tabular}{llllll}
\hline Rated Factors & Excellent & Very good & Good & Poor & Very poor \\
\hline Design to improve concentration & 6 & 4 & 0 & 0 & 0 \\
Adequate facilities & 8 & 2 & 0 & 0 & 0 \\
Design to improve privacy & 3 & 7 & 0 & 0 & 0 \\
\hline Total & 17 & 13 & 0 & 0 & 0 \\
\hline
\end{tabular}

Figure 15. Student opinion. Source: Personal Source

on average 2-4 hours each day. Another questionnaire was also conducted to review the student bedroom design for $10 \%$ of the previous respondents, as seen in Figure 15.

This research is preliminary research for online study space planning. For more accurate results it is necessary to study this topic in more detail and depth.

\section{ACKNOWLEDGMENTS}

This paper was (a) research search conducted by the first author, and also became joint research with a student at Telkom University for her practical work and the third author. This research wouldn't have occurred without the data provided from all respondents from different design majors.

\section{REFERENCES}

Badan Standar Nasional Pendidikan. 2011. Rancangan Standar Saran dan Prasarana Pendidikan Tinggi Program Pascasarjana dan Profesi, Pemerintah Indonesia.

Ching, Francis D.K. 1994. Terjemahan oleh Paulus H. Adjie. Arsitektur, Bentuk Ruang dan Susunannya. Jakarta: Erlangga

Donny Trihanondo SDs., MDs, Tri Haryotedjo SDs., MDs., Iqbal Prabawa Wiguna SSn.,MSn. 2017, Pisikologi Ruangan pada Program Studi Intermedia dalam Mendukung Atmosfer Akademik, 490

Neufert, Ernst. 1996. Terjemahan oleh Dr. Ing Sunarto Tjahjadi, jilid 1, Data Arsitek. Jakarta: Erlangga

Panero, Julius and Martin Zelnik. 2003. Dimensi Manusia \& Ruang Interior. Jakarta: Erlangga.

Rapoport, Amos. 1977. Human Aspects of Urban Form: Towards A Man-Environmental Approach to Urban Form And Design, New York: Pergamon Press.

https://jabar.suara.com/read/2020/06/03/090839/sekolah-di-jawa-barat-masih-tutup-sampai-januari2021-belajar-di-rumah accessed May 2020

https://www.kompas.com/tren/read/2020/07/03/155830065/menteri-nadiem-wacanakan-belajar-jarakjauh-permanen-setelah-pandemi-covid accessed May 2020 